\title{
Analysis of misdiagnosed cases of hemorrhagic fever with renal syndrome in children: two cases and literature review
}

\author{
Li Zhang, Qing-shan Ma*i(B, Yan Zhang, Bai-chao Sun and Leng-yue Zhao
}

\begin{abstract}
Background: Hemorrhagic fever with renal syndrome (HFRS) is an acute disease caused by hantavirus infection and is clinically characterized by fever, various hemorrhagic manifestations and transient renal and hepatic dysfunctions. Although various cases of HFRS have been reported, cases in children have rarely been described. Herein, we report two atypical cases of HFRS in children without distinctive manifestations and typical disease clinically progresses.
\end{abstract}

Case presentation: Patient 1 was a 11-year-old girl who attended our clinic for fever accompanying with acute renal failure, proteinuria and decreased level of complement $3\left(C_{3}\right)$ and thrombocytopenia without any hemorrhagic manifestations, acute glomerulonephritis was suspected first, especially lupus nephritis. Patient 2 was misdiagnosed as encephalitis at local hospital because of fever and headache for 4 days. With elevated liver transaminases, proteinuria and normal cerebrospinal fluid examination, HFRS was taken into consideration. Both of the two cases were supported and confirmed by serological test for Hantavirus.

Conclusions: Clinical manifestations of HFRS in children often presented atypically and were milder than adults. Febrile disease accompanying with thrombocytopenia may lead to the suspected diagnosis of HFRS.

Keywords: Hemorrhagic fever with renal syndrome, Children, Atypical, Hantavirus

\section{Background}

HFRS is a zoonosis caused by viruses that belong to the genus Hantavirus [1], which is prevalent among European and Asian countries [2]. It typically presents itself with the triad of fever, hemorrhage, and acute kidney injury [3]. The disease may manifest itself in five distinct phases that are characterized by the presence of fever, hypotension, oliguria, diuresis and convalescence. While most reported cases have been reported in adults $[4,5]$, children with this illness may have atypical presentations that lead to delayed or missed diagnosis. We herein reported two children with HFRS, whose diagnoses were both delayed due to atypical presentations.

\section{Case presentation}

\section{Patient 1}

A 11-year-old girl from a rural village attended our clinic with a history of fever and cough since 6 days prior. She also complained of muscle weakness and fatigue, and had a decrease in urine output and swelling eyes. Physical examination revealed with mild eyelids and facial edema, facial blushing, oral ulcer, throat congestion and bilateral vertebral angle tenderness. Family history was significant for father who recovered from acute kidney injury with unknown etiology 1 year ago.

Vital signs were stable (BP 96/80 mmHg, P 106/min, R 24/ $\mathrm{min}$ ) and laboratory investigations were depicted in Table 1. In summary, she got leucocytosis $\left(20.0 \times 10^{9} / \mathrm{L}\right.$, with $64 \%$ neutrophils), normal hemoglobin and thrombocytopenia $\left(66 \times 10^{9} / \mathrm{L}\right)$ shown in routine blood analysis. She got elevated hepatic transaminases (ALT $228 \mathrm{U} / \mathrm{L}$, AST $235 \mathrm{U} / \mathrm{L}$ ) and lactate dehydrogenase (764 U/L). In addition, her blood urea nitrogen and creatinine were $13.32 \mathrm{mmol} / \mathrm{L}$ and $104 \mu \mathrm{mol} / \mathrm{L}$ respectively, which were elevated than normal,
* Correspondence: maqingshan1024@163.com

Department of Pediatrics Nephrology, First Hospital, Jilin University, Changchun 130021, Jilin, China (c) The Author(s). 2019 Open Access This article is distributed under the terms of the Creative Commons Attribution 4.0 International License (http://creativecommons.org/licenses/by/4.0/), which permits unrestricted use, distribution, and reproduction in any medium, provided you give appropriate credit to the original author(s) and the source, provide a link to the Creative Commons license, and indicate if changes were made. The Creative Commons Public Domain Dedication waiver (http://creativecommons.org/publicdomain/zero/1.0/) applies to the data made available in this article, unless otherwise stated. 
Table 1 Overview of laboratory investigations in Patient 1

\begin{tabular}{|c|c|c|c|c|c|c|c|}
\hline Laboratory finding & Normal range & Clinic & Day 1 & Day 2 & Day 4 & Day 6 & Day 8 \\
\hline$\overline{\mathrm{WBC}\left(\times 10^{9} / \mathrm{L}\right)}$ & $3.50-9.50$ & 20.00 & 20.78 & & 10.62 & 7.17 & \\
\hline GR\% & $40-75$ & 64 & 37 & & 58 & 46 & \\
\hline $\mathrm{GR \#}\left(\times 10^{9} / \mathrm{L}\right)$ & $1.80-6.30$ & 12.3 & 7.70 & & & 3.31 & \\
\hline LY\% & $20-50$ & 21.9 & 47 & & 25 & 32 & \\
\hline $\mathrm{LY \#}\left(\times 10^{9} / \mathrm{L}\right)$ & $1.10-3.20$ & 4.38 & 9.83 & & & 2.31 & \\
\hline $\mathrm{HGB}(\mathrm{g} / \mathrm{L})$ & $115-150$ & 155 & 146 & & & 144 & \\
\hline $\operatorname{PLT}\left(\times 10^{9} / \mathrm{L}\right)$ & $125-350$ & 66 & 106 & & & 473 & \\
\hline $\mathrm{ALT}(\mathrm{U} / \mathrm{L})$ & $9.0-50.0$ & 228 & 141 & & & & 22 \\
\hline AST (U/L) & $15.0-40.0$ & 235 & 141 & & & & 28 \\
\hline $\mathrm{LDH}(\mathrm{U} / \mathrm{L})$ & $120-250$ & 764 & 660 & & 462 & & 293 \\
\hline $\mathrm{HBD}(\mathrm{U} / \mathrm{L})$ & $72.0-182.0$ & 537 & 517 & & & & 236 \\
\hline $\mathrm{Ca}(\mathrm{mmol} / \mathrm{L})$ & $2.25-2.67$ & 1.93 & / & 1.97 & / & / & 2.42 \\
\hline $\mathrm{ALB}(\mathrm{g} / \mathrm{L})$ & $40.0-55.0$ & 33.7 & 32.4 & & & & 38.1 \\
\hline Ferritin $(\mu \mathrm{g} / \mathrm{L})$ & $20.0-200.0$ & / & / & 1291.5 & & & 149.4 \\
\hline$C_{3}(g / L)$ & $0.9-1.5$ & / & / & 0.73 & 0.99 & & \\
\hline $\mathrm{CRP}(\mathrm{mg} / \mathrm{L})$ & $0.00-3.00$ & & & 14.2 & 10.60 & & \\
\hline BUN (mmol/L) & $2.6-7.5$ & 13.32 & 12.47 & 11.44 & & 8.72 & 5.50 \\
\hline $\operatorname{Scr}(\mu \mathrm{mol} / \mathrm{L})$ & $50-80$ & 104 & 96.2 & 99.8 & 122.7 & 75.3 & 57.9 \\
\hline eGFR (ml/min) & $80-120$ & 64 & 69 & & 54.3 & 88.5 & \\
\hline Proteinuria (g/24 h) &,$- 0-0.15$ & $3+$ & & $2+$ & 1.24 & - & 0.02 \\
\hline Hematuria (/HPF) &,$- 0-3$ & $2+, \mathrm{RBC}$ 1.3/HPF & & & & & \\
\hline$M P-A b$ & $<1: 40$ & & & $1: 80$ & & & \\
\hline $\begin{array}{l}\text { IgM capture ELISA } \\
\text { anti- Hantaan virus }\end{array}$ & - & / & / & / & / & + & \\
\hline
\end{tabular}

MPMycoplasma pneumoniae

Ab Antibody

ELISA Enzyme-linked immuno sorbent assay

and the eGFR declined to $64 \mathrm{ml} / \mathrm{min}$. Her albumin $(33.7 \mathrm{~g} / \mathrm{L})$ and total calcium $(1.93 \mathrm{mmol} / \mathrm{L})$ both declined. Routine urine analysis showed proteinuria (3+) and hematuria (2+) with normal number RBC in HPF. Renal ultrasonography showed swelling of both kidneys, increase in echogenicity and reduced corticomedullary differentiations without urinary lithiasis.

On the basis of these, it seemed like some kind of acute glomerulonephritis acquired after infection. In order to identify the diagnosis, she was admitted to our department. As she was an adolescent girl with fever, oral ulcer, thrombocytopenia, proteinuria, hematuria, and especially with $C_{3}$ levels declined which was found on the second day after hospitalizing, systemic lupus erythematosus (SLE) was taken into consideration first. Besides, her father had fallen into renal failure before, which provided Alport Syndrome as another speculation. Another abnormal index was elevated ferritin, combined with changes in routine blood analysis, which made bone marrow puncture be needed. Because of the benign prognosis of most post-infection glomerulonephritis, renal biopsy is not necessary in most cases. However, her urine protein quantity was $1.24 \mathrm{~g} / 24 \mathrm{~h}$, which was rather high for children, renal biopsy was under consideration. The titer of Mycoplasma pneumoniae (MP) antibody increased to 1:80. MP infection could also cause extrapulmonary injury, such as hepatic function impairment and nephritis. Along with fever, she got transient nausea and vomiting on the third day. Antibiotics and supporting treatment were given to her. Taking into account the diseases mentioned earlier, we were going to give her kinds of invasive examination. Fortunately, the abnormal indexes recovered gradually after symptomatic treatment, shown in Table 1. On day five, she no longer got fever. On day six serum was found positive for Hantaan virus IgM antibody which using the method of IgM capture ELISA.

When we repeated the history regarding possible rodent exposure, her family stated that there were a lot of rodent activity and patients diagnosed as epidemic hemorrhagic disease in their place of residence. During the disease evolution, febrile stage and oliguria stage appeared at the 
same time, and diuresis stage appeared on the 5th day without hypotension. She recovered well with supportive treatment without residual complications.

\section{Patient 2}

A 13-year-old girl was transferred from a local hospital to our department with a diagnosis of encephalitis because of fever and headache for 4 days. She also complained of orbital and abdominal pain. Upon presentation, her vital signs were normal (BP 110/70 mmHg, P 100/min, R 24/min) and physical examination included facial blushing when fever, pale face and palpebral conjunctiva, throat congestion, splenomegaly (spleen located in subcostal arch $2 \mathrm{~cm}$ ) and negative nervous system examination.

Cerebrospinal fluid examination taken in clinic was normal (protein $0.24 \mathrm{~g} / \mathrm{L}$, glucose $6.38 \mathrm{mmol} / \mathrm{L}$, chlorine 121.7 mmol/L, Pan's reaction: negative, WBC $7 \times 10^{6} / \mathrm{L}, \mathrm{RBC}$ $0 \times 10^{6} / \mathrm{L}$ ). Routine blood analysis in clinic showed leucocyte with left shift $\left(5.60 \times 10^{9} / \mathrm{L}\right.$, with $89 \%$ neutrophils $)$, mild anemia (HGB $97 \mathrm{~g} / \mathrm{L}$ ) and normal quantity of platelet $\left(172 \times 10^{9} / \mathrm{L}\right)$ which declined to $104 \times 10^{9} / \mathrm{L}$ for the next day. Liver transaminases (ALT $143 \mathrm{U} / \mathrm{L}$, AST $96 \mathrm{U} / \mathrm{L}$ ) and lactate dehydrogenases $(638 \mathrm{U} / \mathrm{L})$ were both elevated. Urine showed proteinuria (3+), meanwhile both blood urea nitrogen and creatinine were normal. Renal imaging also showed renal swelling (Left: $125 \mathrm{~mm} \times 59 \mathrm{~mm}$; Right: 124 $\mathrm{mm} \times 57 \mathrm{~mm}$; Normal range: Left: (93.2-105.2) $\mathrm{mm} \times$ (47.6-54.6) mm; Right: (84.1-94.9) $\mathrm{mm} \times(44.7-51.9) \mathrm{mm}$ ) and poor corticomedullary differentiation. In addition, the ferritin was $444.6 \mu \mathrm{g} / \mathrm{L}$ which was elevated and heteromorphic lymphocyte (17\%) was seen in blood smear examination. The titer of MP antibody increased to 1:80. Detailed laboratory investigations were depicted in Table 2.

The patient presented headache and fever in autumn, which easily led pediatrician to take encephalitis into consideration first. However, with the normal cerebrospinal fluid examination in clinic and negative nervous system examination in our department, it was ambiguous to make the diagnosis as encephalitis. Due to mild anemia and thrombocytopenia, accompanying with elevated ferritin and heteromorphic lymphocyte, we had to decide whether or not to do a bone marrow puncture. In addition, with damage in hematological system accompanied with proteinuria occuring in an adolescent girl, we should also pay attention to identification of SLE. As her complain of orbital pain, HFRS was also taken into consideration. Despite the possibility, the consultation from infectious disease department did not consider HFRS at first.

Table 2 Overview of laboratory investigations in Patient 2

\begin{tabular}{|c|c|c|c|c|c|c|c|}
\hline Laboratory finding & Normal range & Clinic & Day 1 & Day 2 & Day 3 & Day 6 & Day 10 \\
\hline$\overline{W B C}\left(\times 10^{9} / \mathrm{L}\right)$ & $3.50-9.50$ & 5.60 & 5.69 & 7.84 & 10.01 & 5.66 & 6.30 \\
\hline GR\% & $40-75$ & 89 & 45 & 24 & 21 & 41 & 38 \\
\hline $\mathrm{GR \#}\left(\times 10^{9} / \mathrm{L}\right)$ & $1.80-6.30$ & & 2.55 & 1.88 & 2.14 & 2.31 & 2.37 \\
\hline LY\% & $20-50$ & 8 & 31 & 50 & 66 & 48 & 56 \\
\hline LY\# $\left(\times 10^{9} / L\right)$ & $1.10-3.20$ & & 1.76 & 3.89 & 6.62 & 2.72 & 3.53 \\
\hline $\mathrm{HGB}(\mathrm{g} / \mathrm{L})$ & $115-150$ & 97 & 89 & 91 & 81 & 81 & 87 \\
\hline $\operatorname{PLT}\left(\times 10^{9} / \mathrm{L}\right)$ & $125-350$ & 172 & 104 & 146 & 111 & 190 & 409 \\
\hline $\mathrm{ALT}(\mathrm{U} / \mathrm{L})$ & $9.0-50.0$ & & & 143 & & & \\
\hline AST (U/L) & $15.0-40.0$ & & & 96 & & & \\
\hline LDH (U/L) & $120-250$ & & & 638 & & & \\
\hline $\mathrm{HBD}(\mathrm{U} / \mathrm{L})$ & $72.0-182.0$ & & & 441 & & & \\
\hline $\mathrm{Ca}(\mathrm{mmol} / \mathrm{L})$ & $2.25-2.67$ & & 1.87 & 1.95 & 2.01 & 1.83 & 2.17 \\
\hline $\operatorname{ALB}(g / L)$ & $40.0-55.0$ & & & 34.2 & & & \\
\hline Ferritin $(\mu \mathrm{g} / \mathrm{L})$ & $20.0-200.0$ & & & 444.6 & & & \\
\hline CRP (mg/L) & $0.00-3.00$ & & 11.90 & & & 1.76 & \\
\hline BUN (mmol/L) & $2.6-7.5$ & & 3.41 & 3.38 & 2.73 & 1.86 & 3.32 \\
\hline $\operatorname{Scr}(\mu \mathrm{mol} / \mathrm{L})$ & $50-80$ & & 44 & 58.6 & 50 & 48.4 & 35.6 \\
\hline Proteinuria (g/24 h) &,$- 0-0.15$ & & $2+$ & $1+$ & $3+$ & & \\
\hline$M P-A b$ & $<1: 40$ & & & $1: 80$ & & & \\
\hline IgM capture ELISA anti- Hantaan virus & - & / & / & / & + & & \\
\hline
\end{tabular}

MP Mycoplasma pneumoniae

$A b$ Antibody

ELISA Enzyme-linked immuno sorbent assay 
HFRS was later supported and confirmed by her serological test for Hantaan virus on the 3rd day, which was positive. Then she was transferred to infectious disease department for treatment including antiviral drugs and supporting treatment. During the disease evolution, diuresis stage appeared on the 7th day without oliguria stage and hypotension. Although she discharged hospital from another department, she was under follow-up by pediatrician. After accepting supportive therapy, she also recovered well.

\section{Discussion and conclusions}

HFRS is an acute illness caused by Hantavirus in the family Bunyaviridae. It is a kind of zoonosis. Infection of humans by different viruses presents different clinical severities. The most commonly found species in Western-Europe is Puumala virus [6], which usually caused a milder form HFRS. Especially, infection among children are much lighter than adults [7]. While in Asia, mainly in China, Hantaan virus (HTNV) and Seoul virus (SEOV) are the common species $[8,9]$, that often cause the more severe form HFRS. It is notable that a novel European hantavirus, Sochi virus, has been discovered which causes severe courses of hantavirus disease with a high mortality [10]. Besides HFRS, Hantavirus could cause hantavirus cardiopulmonary syndrome (HCPS) or hantavirus pulmonary syndrome (HPS).

Human infection occurs primarily through via viruscontaining, aerosolized rodent excretions such as urine, feces, or saliva [11]. It is more prevalent among rural inhabitants where rodent infestations are common. Rodents act as natural habours of the Hantavirus and can transmit the disease through direct innoculation by biting. Victims can also be infected via contact with rodent dropplings that are contaminated with the virus [12]. Although both of our patients denied being bitten by mice, they might have contacted contaminated dropplings without notice. In addition, the father of our first patient had similar clinical presentation a year ago supports the postulation that they both might have been exposed to Hantavirus in the same environment.

The disease constellations of HFRS include fever, various hemorrhagic manifestations and transient hepatic/ renal functions impairments [13]. It generally progresses in five distinct phases, including fever, hypotension, oliguria, diuresis and convalescence [14]. The presence of endothelial damages, as evidenced by capillary dilatation and leakage, is considered to be a hallmark of the hantavirus infection [15]. Although the exact pathomechanisms are unclear, the clinical conundrum of marked cytokines production, kallikrein-kinin and complements activations, and elevated levels of circulating immune complexes suggest the pivotal roles of immune responses to the infection.
Although hantavirus infection is a global health issue [16], about $90 \%$ of reported cases are from China [17]. Even though childhood infections were not common among reported cases, this phenomenon might be due to underdiagnosis, as the clinical manifestations of HFRS in children can be atypical [12]. Meanwhile, it is reported that the clinical impression of HFRS is lighter in children than in adults [7]. In their review, they concluded three aspects of difference. First, in clinical symptoms aspect, adults usually had arthralgia, muscle pain and visual disturbances, while abdominal pain and vomiting was more common in children than in adults. Second, in aspect of physical signs, transient hypertension was more common in the children. Third, in laboratory tests almost all adults had significant leukocytosis, whereas in children the most common laboratory finding was thrombocytopenia. However, a recent analysis pointed different view [18]. Despite some certain differences among symptoms, acute kidney injury (AKI) and thrombocytopenia occurred at similar frequencies and severity in both children and adults. Another research claimed that the presence of thrombocytopenia is highly sensitive and specific for detecting patients with hantavirus infection [19]. Platelet count was also a predictor and marker of disease severity and progression [20, 21].

In childhood, hantavirus infection is not an common etiology of acute kidney injury. The diagnosis of HFRS is based on clinical manifestation, epidemiological data and laboratory tests. However, in cases with mild or atypical clinical symptoms, it is hard to diagnosis only based on clinical symptoms or signs. Under these situations, laboratory tests turn out to be of great importance. The most common serological tests are indirect IgM and IgG ELISA as well as IgM capture ELISA [22, 23]. Besides, the hantavirus infection can be confirmed by detection of hantavirus genome in blood or serum samples by RTPCR. Consider the economic, we adopted the method of IgM capture ELISA in our center. Both of two patients were confirmed by positive result for Hantaan virus IgM antibody. Still, it often takes a long time to get serological tests result to support a presumptive diagnosis. When we reviewed the course of diagnosis and treatment, we tired to work out which symptoms led to the suspected diagnosis. In Patient 1, besides of fever, she demonstrated acute hepatic and kidney injuries associated with thrombocytopenia and low $\mathrm{C}_{3}$ level, but she did not have any clinical feature of hemorrhage, nor did her physical signs reveal any hypertension. Besides, both fever and thrombocytopenia could happen in either blood disease or autoimmune disease, which made us almost give her a bone marrow puncture and a kidney biopsy. Also she did not presented in typical five different phases. Therefore, her hantavirus infection was not ascertained until the serological results were later confirmed. The delay in serological tests caused a dilemma 
in initial examination and treatment. Similarly, in Patient 2 , her presentation of fever with severe headache had also rendered the diagnosis of HFRS a challenge during her initial clinical course. Although there was nausea and vomiting in Patient 1 and abdominal pain in Patient 2 , these symptoms were not of specificity. Besides, hybrid infections often occur in children, such as MP infection in both patients, which could also make us confused. From former literature and our case presentations, fever accompanying with thrombocytopenia in both patients might lead to suspected diagnosis of HFRS. It gave us a reminder to consider HFRS and distinguish from other diseases.

The transient decline of $C_{3}$ level in Patient 1 might support that the immune mechanisms play an important role in the pathogenesis of HFRS. Their platelet counts recovered soon presented that they were under a milder disease course as well. There was splenomegaly, anemia and heteromorphic lymphocyte in Patient 2, that probably due to inflammation in the spleen. The inflammation in the spleen was reported in hantavirus infections in hosts [24]. However, that could not be identified, as we did not do bone marrow puncture nor any further examinations. It was a limitation that we did not do renal biopsy for them, so that we could not recognize the renal pathology of HFRS. Since they had complete recovery, it was benefit for patients not undergoing invasive examinations.

In case of hantavirus infection there is no specific treatment. Generally the primary treatment of hantavirus infection is mainly supportive. Renal function recovers completely within a few days in most cases. Hemodialysis, oxygen therapy and shock therapy are sometimes needed. However, when it came to the conditions with deadly hantavirus infections, there is an increasing demand to develop special therapy. Under the known pathogenesis, drugs that are known to influence increased capillary permeability, such as kinases, angiopoietin 1 and sphingosine 1 phosphate are in clinical trials [25]. Luckily, both of our patients suffered mild manifestation and recovered fully without any residual damage after supportive treatment. What needs to be explained is that our Patient 2 accepted antiviral drug (ribavirin) in infectious disease department. Controversy has arisen in whether or not using ribavirin in treatment of HFRS. A previous trial, in which prospective, double-blind, concurrent, placebocontrolled method was used to observe the effect of intravenous ribavirin therapy of HFRS in China, reported that both morbidity and mortality significantly declined [26]. However, a recent trial for the treatment of HFRS in Russia indicated that intravenous ribavirin did not alter viral load kinetics [27]. Consider the side effect of using ribavirin in children, we do not recommend that children are treated with ribavirin for HFRS. The best defence would be to prevent serious infection from occurring. Since there are no FDAapproved vaccines or treatments for these hantavirus diseases by now [28], it is urgent for the development of vaccines in postexposure prophylactic.

Our patients illustrate how HFRS in children is a clinical entity with multiple manifestations, and high index of suspicions are vital in making the correct diagnosis. When facing unexplaned fever accompanying with thrombocytopenia, pediatricians should take HFRS into consideration. Serological test should be adopted for diagnose in time. Early acknowledge could avoid unnecessary invasive examinations and treatment delay.

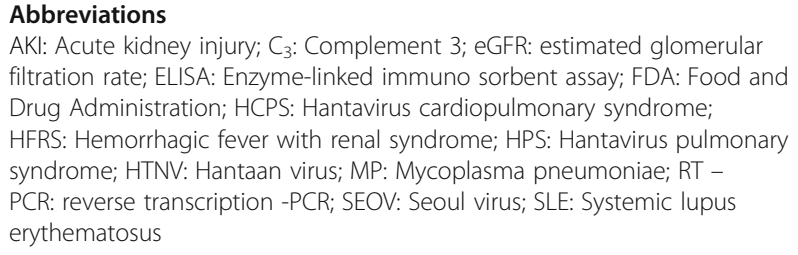

\section{Acknowledgements}

We thank the patients, their families and authors who participated in this study. At the same time, we thank Professor Keithk Lau of University of Hong Kong for revising the language of the article.

\section{Authors' contributions}

LZ collected the clinical information and wrote the manuscript. YZ, BCS and LYZ supported the data collection, interpretation of the data. QSM was involved in revising the manuscript critically for important intellectual content. All authors read and approved the final manuscript.

\section{Funding}

No funding.

Availability of data and materials

The datasets used analyzed during the current study are available from the corresponding author on reasonable request.

Ethics approval and consent to participate Not applicable.

\section{Consent for publication}

Written informed consent was obtained from the parents of both patients for publication of this Case Report. A copy of the written consent is available for review by the Editor of this journal.

\section{Competing interests}

The authors declare that they have no competing interests.

Received: 17 March 2019 Accepted: 20 September 2019 Published online: 23 October 2019

\section{References}

1. Ferrés M, Vial P. Hantavirus infection in children [J]. Curr Opin Pediatr. 2004; 16(1):70-5.

2. Piechotowski I, Brockmann SO, Schwarz C, Winter CH, Ranft U, Pfaff G. Emergence of hantavirus in South Germany: rodents, climate and human infections. Parasitol Res. 2008;103:S131-7.

3. Jiang H, Du H, Wang LM, et al. Hemorrhagic Fever with Renal Syndrome: Pathogenesis and Clinical Picture[J]. Frontiers in Cellular and Infection Microbiology. 2016;6:1. https://doi.org/10.3389/fcimb.2016.00178. 
4. Park Y. Epidemiologic study on changes in occurrence of hemorrhagic fever with renal syndrome in Republic of Korea for 17 years according to age group: 2001-2017[]]. BMC Infect Dis. 2019;19(1):153.

5. Zhao Q, Yang X, Liu H, et al. Effects of climate factors on hemorrhagic fever with renal syndrome in Changchun, 2013 to 2017[]]. Medicine. 2019;98(9):e14640.

6. Kruger DH. Tadeu Moraes Figueiredo L, song J-W, Klempa B. hantaviruses_-globally emerging pathogens. J Clin Virol. 2015;64:128-36.

7. Huttunen NP, Mäkelä S, Pokka T, et al. Systematic literature review of symptoms, signs and severity of serologically confirmed nephropathia epidemica in paediatric and adult patients []]. Scand J Infect Dis. 2011;43(6-7):6.

8. Zhang WY, Fang LQ, Jiang JF, Hui FM, Glass GE, Yan L, et al. Predicting the risk of hantavirus infection in Beijing, People's Republic of China. Am J Trop Med Hyg. 2009;80(4):678-83.

9. Li L, Wang $\mathrm{CH}$, Wang $\mathrm{SF}$, et al. Hemorrhagic fever with renal syndrome in China: mechanisms on two distinct annual peaks and control measures[]]. Int J Biomath. 2018;11(2):1850030. https://doi.org/10.1142/ S1793524518500304.

10. Dzagurova TK, Tkachenko EA, Ishmukhametov AA, et al. Severe hantavirus disease in children [J]. J Clin Virol. 2018;101:66-8.

11. Walter M, Udo B, Martin Z, et al. Hantavirus infection. J Am Soc Nephrol. 2005;16:3669-79.

12. Fidan $\mathrm{K}$, Polat $\mathrm{M}$, Isiyel $\mathrm{E}$, et al. An adolescent boy with acute kidney injury and fever. Hemorrhagic fever with renal syndrome (HFRS).[J]. Pediatr Nephrol. 2013;28(11):2115-6.

13. Yoo KH, Choi Y. Haemorrhagic fever with renal syndrome in Korean children. Korean Society of Pediatric Nephrology.[J]. Pediatr Nephrol. 1994;8(5):540-4.

14. Vaheri A, et al. Hantavirus infections in Europe and their impact on public health. Rev Med Virol. 2013;23:35-49.

15. Rista E, Pilaca A, Akshija I, et al. Hemorrhagic fever with renal syndrome in Albania. Focus on predictors of acute kidney injury in HFRS [J]. Journal of clinical virology the official publication of the Pan American Society for Clinical. Virology. 2017;91:25.

16. Jiang $H$, Zheng $X$, Wang $L$, et al. Hantavirus infection: a global zoonotic challenge [J]. Virol Sin. 2017;32(1):1-12.

17. Xiao H, Tian HY, Gao LD, et al. Animal reservoir, natural and socioeconomic variations and the transmission of hemorrhagic fever with renal syndrome in Chenzhou, China, 2006-2010[J]. PLoS Negl Trop Dis. 2014;8(1):e2615.

18. Echterdiek F, Kitterer D, Alscher MD, et al. Clinical course of hantavirusinduced nephropathia epidemica in children compared to adults in Germany-analysis of 317 patients[]]. Pediatr Nephrol. 2019;34(7):1247-52.

19. Navarrete M, Hott M, Caroca J, et al. Correlation between clinical and laboratory criteria of suspected hantavirus cases and the results of the reference diagnostic technique. Rev Chil Infectol. 2016;33(3):275-28.

20. Wang M, Wang J, Wang T, Li J, Hui L, Ha X. Thrombocytopenia as a predictor of severe acute kidney injury in patients with Hantaan virus infections. PLoS One. 2013;8(1):e53236.

21. Rasche FM, Uhel B, Kruger DH, Karges W, Czock D, Hampl W, Keller F, Meisel $\mathrm{H}$, von Muller L. Thrombocytopenia and acute renal failure in Puumala hantavirus infections. Emerg Infect Dis. 2004;10(1):1420-5.

22. Avšič-Županc T, Saksida A, Korva M. Hantavirus infections. Clin Microbiol Infect. 2015;21S:e6-e16. https://doi.org/10.1111/1469-0691.12291.

23. Jonsson $C B$, Figueiredo LT, Vapalahti O. A global perspective on hantavirus ecology, epidemiology, and disease.[]]. Clin Microbiol Rev. 2010;23(2):412-41.

24. Easterbrook JD, Klein SL. Immunological mechanisms mediating hantavirus persistence in rodent reservoirs. PLoS Pathog. 2008;4:e1000172.

25. Gavrilovskaya IN, Gorbunova EE, Mackow NA, Mackow ER. Hantaviruses direct endothelial cell permeability by sensitizing cells to the vascular permeability factor VEGF, while angiopoietin 1 and sphingosine 1-phosphate inhibit hantavirus-directed permeability. J Virol. 2008;82:5797-806.

26. Huggins JW, Hsiang CM, Cosgriff TM, et al. Prospective, double-blind, concurrent, placebo-controlled clinical trial of intravenous ribavirin therapy of hemorrhagic fever with renal syndrome [J]. J Infect Dis. 1991;164(6):1119-27.

27. Malinin OV, Platonov AE. Insufficient efficacy and safety of intravenous ribavirin in treatment of haemorrhagic fever with renal syndrome caused by Puumala virus [J]. Infectious Diseases. 2017:49(7):514-20.

28. Brocato RL, Hooper JW. Progress on the prevention and treatment of hantavirus disease. Viruses. 2019;11(7):610.

\section{Publisher's Note}

Springer Nature remains neutral with regard to jurisdictional claims in published maps and institutional affiliations.

\section{Ready to submit your research? Choose BMC and benefit from}

- fast, convenient online submission

- thorough peer review by experienced researchers in your field

- rapid publication on acceptance

- support for research data, including large and complex data types

- gold Open Access which fosters wider collaboration and increased citations

- maximum visibility for your research: over $100 \mathrm{M}$ website views per year

At BMC, research is always in progress.

Learn more biomedcentral.com/submissions 